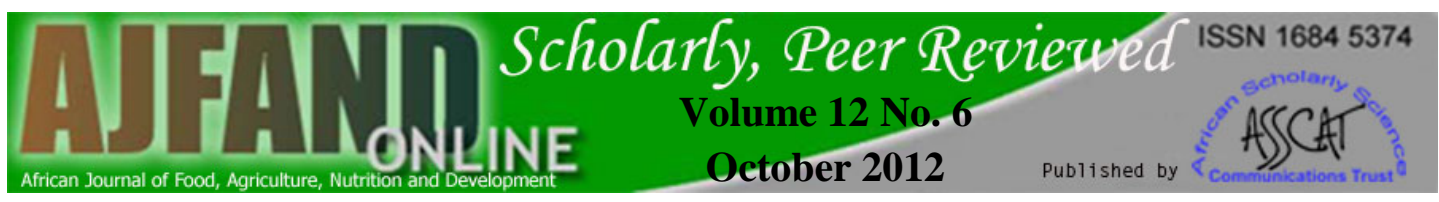

\title{
EFFECT OF GARRI PROCESSING EFFLUENTS [WASTE WATER] ON THE CYANIDE LEVEL OF SOME ROOT TUBERS COMMONLY CONSUMED IN THE SOUTH EAST OF NIGERIA
}

\section{Uhegbu FO $^{1 *}$, Akubugwo EI ${ }^{1}$ and EEJ Iweala ${ }^{2}$}

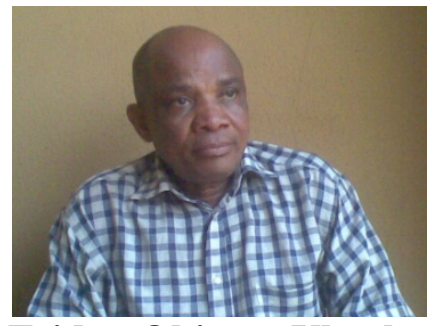

Friday Obinwa Uhegbu

*Corresponding author email: fouhegbu@yahoo.com

${ }^{1}$ Department of Biochemistry, Abia State University, PMB 2000, Uturu, Nigeria.

${ }^{2}$ Department of Biological Sciences, Covenant University, Ota, Nigeria. 


\section{ABSTRACT}

Root tubers are the important staple food crops in the tropics, Nigeria inclusive. In the South East of Nigeria, the major staple root tuber crops include Dioscorea rotundata, (White yam) Dioscorea alata, (Water yam) Xanthosoma sagittifolium, (Red Cocoyam) Colocasia esculenta, (White Cocoyam) Ipomea batatas (Sweet potato) and Dioscorea dumetorum (Domestic yam). Due to inadequacies in supply, these tubers are always in high demand by consumers. To make up for the high demand, peasant farmers cultivate these tubers in any available space around homes. Around most homes in the villages are garri (cassava flour) processing factories, with the effluents (waste water) allowed to flow into adjoining farmlands without any form of treatment. It has been reported that cassava tubers and their effluents contain high concentrations of cyanide, thus the cyanide in the effluent may be adsorbed by the soil onto which it is disposed. Plants that are grown on soil of low potassium content and high nitrogen content have been reported to have high hydrocyanic acid concentration in their tubers. Numerous studies have described environmental exposure of humans to cyanide in African populations. Little is known about exposure to cyanide toxins from processed or unprocessed root tubers commonly consumed in Africa; and data on the food concentration of cyanide which is a potential poison and systemic toxicant is scanty. This study determined the concentrations of cyanide in some root tubers grown in a cassava processing plant effluent [waste water] contaminated farm land and commonly consumed in South East of Nigeria. Dioscorea rotundata had $10.13 \pm 1.9 \mathrm{mgHCN} / \mathrm{kg}$, while Dioscorea alata had $9.12 \pm 0.93 \mathrm{mgHCN} / \mathrm{kg}$. Xanthosoma sagittifolium and Colocasia esculenta were found to have values of $15.19 \pm 1.69 \mathrm{mgHCN} / \mathrm{kg}$ and $11.81 \pm 1.19 \mathrm{mgHCN} / \mathrm{kg}$, respectively. Ipomea batatas [red cultivar] had cyanide level of $8.44 \pm 1.20 \mathrm{mgHCN} / \mathrm{kg}$, while the white cultivar had $8.44 \pm 1.20 \mathrm{mgHCN} / \mathrm{kg}$. Dioscorea dumetorum [domestic] showed cyanide level of $35.44 \pm 1.69 \mathrm{mgHCN} / \mathrm{kg}$. These values are significantly $[\mathrm{p}<0.05]$ higher compared to values from the control site for the same cultivars, $9.65 \pm 1.36 \mathrm{mgHCN} / \mathrm{kg}$, $8.45 \pm 1.60 \mathrm{mgHCN} / \mathrm{kg}, \quad 14.77 \pm 1.33 \mathrm{mgHCN} / \mathrm{kg}$ and $10.89 \pm 1.55 \mathrm{mgHCN} / \mathrm{kg}$, respectively while $I$. batatas and $D$. dumetorum had $7.26 \pm 1.34 \mathrm{mgHCN} / \mathrm{kg}$, $32.76 \pm 0.05 \mathrm{mgHCN} / \mathrm{kg}$, respectively. The difference in cyanide content between cultivars from the assumed contaminated site and control site could be as a result of environmental factors, like temperature, humidity, altitude and possibly the cassava effluent [waste water]. This preliminary study highlights the need to study the toxicological implications of chronic low-level exposure to cyanide from African root tubers as a result of poor waste disposal methods.

Key words: Tubers, cyanide, toxicity, soil, contamination

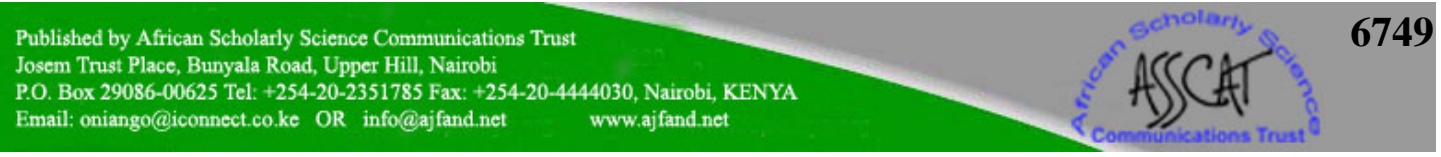




\section{INTRODUCTION}

The deleterious effects of cyanide, even at low concentrations have been widely reported [1, 2]. The lethal dose of hydrocyanic acid [HCN] taken by mouth is 0.5-3.3 $\mathrm{mg} / \mathrm{kg}$ body weight $[3,4]$. There are continuing efforts to further reduce the cyanide levels in plant foods through the production of better cultivars and food processing techniques [5, 6, 7]. Under normal physiological conditions, tissues of cyanophoric plants do not contain free cyanide; rather they contain cyanogenic glycosides, which upon hydrolysis by endogenous glycosidase yield free cyanide which could be toxic to the consumer $[8,9]$. The sources of cyanide found in soil are from disposal of cyanide wastes in landfills, and use of cyanide-containing road salts. Cyanide exists as free and bound cyanide. The free cyanide [HCN] is not found in healthy growing plants, but develops when normal growth has been retarded by drought or other adverse conditions [7]. Plants can also take up cyanide from soils polluted by organic salts containing cyanide ion $\left[\mathrm{CN}^{-}\right]$or cyanides from industrial waste [10]. During the process of producing cassava starch from (Manihot esculenta) roots, large amounts of cyanoglycosides are released, which rapidly decay to $\mathrm{CN}^{-}$following enzymatic hydrolysis. Depending on the varying cyanoglycoside content of the cassava varieties, the cyanide concentration in the wastewater is as high as $200 \mathrm{mg} / \mathrm{l}$. [11].

Ingestion of cyanide containing staple foods such as cassava and forage plants have accounted for many instances of cyanide poisoning in humans and animals [4]. Cyanide is a highly toxic element and has been implicated as a causative agent in certain diseases such as Leber's optical atrophy, tobacco amblyopia, Tropical Ataxic Neuropathy [TAN], endemic goiter and cretinism syndrome [12]. The most important effect of cyanide is the inhibition of tissue respiration [13]. A number of enzymes like catalase, superoxide dismutase, nitrate reductase are inhibited by cyanide, as well as a number of metalloenzymes like alkaline phosphatase, cytosolic $\mathrm{Cu} / \mathrm{Zn}$ superoxide dismutase $[12,14]$. The cyanide ion or radical $\left[\mathrm{CN}^{-}\right]$is the strong poison and is rapidly absorbed from the gastrointestinal tract [GIT]. The actual toxicity depends on the rate of absorption and the ability of the body to dispose of the cyanide [15]. Cyanide concentration of less than $50 \mathrm{mg} / \mathrm{kg}$ in food is slightly poisonous; $80-100 \mathrm{mg} / \mathrm{kg}$ is toxic, while levels above $100 \mathrm{mg} / \mathrm{kg}$ are fatal; and lethal dose of cyanide in adult humans is of the order of $50-60 \mathrm{mg} / \mathrm{kg}[1,16]$. The WHO recommended safe level is $10 \mathrm{mg}$ of $\mathrm{HCN} / \mathrm{kg}$ body weight [17].

Roots and tubers are thickened underground starch storage organs of some plants. Except for cereals, tubers crops are the most important groups of staple foods in the world $[18,19]$. Though important as they may be, tuber crops have hitherto received scanty attention from researchers. Research has been mostly on cash crops, since tubers yield less acceptable industrially processed products. Recently, however, the situation is changing because the quality and quantity of tuber crops have been improved through increased research stimulated by largescale starvation and population explosion [20]. The principal tuber crops of economic importance in Nigeria include Dioscorea rotundata (white yam), Dioscorea alata (water yam), Xanthosoma sagittifolium (white cocoyam), Colocasia esculenta (red cocoyam), Manihot esculenta (cassava), Ipomea batatas (red sweet potato), Ipomea batatas

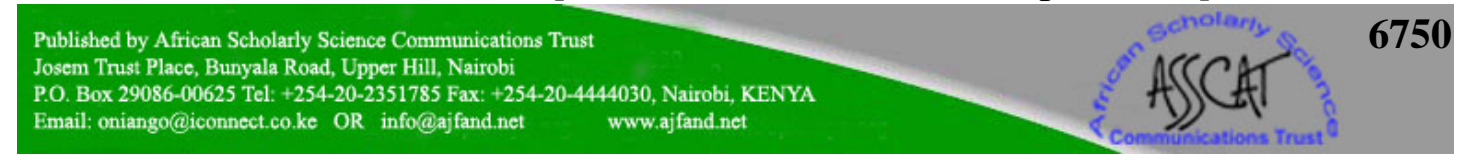


(white sweet potato) and the Dioscorea dumetorum (domestic and wild trifoliate yam) [21].

These tubers are consumed processed in various forms, cooked, boiled, and fried. There are reports of sudden death from consumption of these tubers [22]. It has also been reported [1, 3, 15], that cyanide levels of plants vary according to the environments where they grow.

Hence, it was found necessary to assay for the cyanide levels in some root tubers grown in a cassava processing plant effluent [waste water] contaminated farm land and commonly consumed in South East of Nigeria.

\section{MATERIALS AND METHODS}

\section{Study Area:}

The study area was Umuariaga town in Ikwuano Local Government Area of Abia State Nigeria. The area is popular and known for cassava production all year round, which is readily processed into garri flour. The effluent (waste water) from the "processed" milled cassava is allowed to flow into farmlands where the processing plants are located.

\section{Root tubers:}

Healthy root tuber samples identified and authenticated were collected from the herbarium of the National Roots Crops Research Institute (NRCRI), Umudike.

\section{Planting:}

The tubers were planted on the $1^{\text {st }}$ of April 2010 on both the waste water contaminated site and control (none contaminated) site, and harvested on the $30^{\text {th }}$ day of December, 2010. Planting was done in rows of fours and $64 \mathrm{~m}$ apart. This spacing was to achieve equal nutrient availability for the tubers.

\section{Extraction and Determination of cyanide:}

The samples were washed with distilled water and then ground into a paste in a mortar and used for wet (fresh) analysis. The sample paste (15g) was weighed into a $1000 \mathrm{ml}$ flask and $200 \mathrm{ml}$ distilled water was added and allowed to stand for $4 \mathrm{hr}$. The resulting mixture was then vacuum- distilled and the distillate collected in $20 \mathrm{ml}$ of $\mathrm{NaOH}$ solution, as described by AOAC [23].

The HCN contents of the samples were determined using the alkaline titration method of Association of Official Analytical Chemists [23].The distillate was diluted to $250 \mathrm{ml}$ and an aliquot of $100 \mathrm{ml}$ was titrated by adding $8 \mathrm{ml}$ of $6 \mathrm{~N} \mathrm{NH}_{4} \mathrm{OH}$ solution and $2 \mathrm{ml}$ of $5 \% \mathrm{KI}$ solution. This was then titrated against $0.02 \mathrm{~N} \mathrm{AgNO}_{3}$ solution to get a light turbid end point. The titer values were then used to calculate the cyanide concentrations in $\mathrm{mgHCN} / \mathrm{kg}$.

$\left[1 \mathrm{ml}\right.$ of $\left.0.02 \mathrm{~N} \mathrm{AgNO}_{3}=1.08 \mathrm{mgHCN}\right]$.

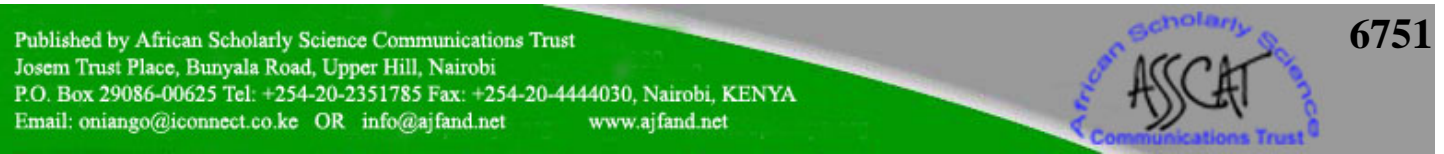




\section{Statistical Analysis:}

Values are represented as mean \pm SEM. Data were analyzed using one-way analysis of variance (ANOVA) followed by Fisher LSD test at 5\%. Differences between test and control were considered significant for $\mathrm{p}<0.05$.

\section{RESULTS}

Table 1 shows the cyanide levels of the root tubers for the cassava processing plant effluent site and the control site. For $D$ dumetorum (domestic), cyanide level at the effluent (waste water) site is $35.49 \pm 1.69 \mathrm{mgHCN} / \mathrm{kg}$, which is significantly $(\mathrm{p}<0.05)$ higher than the control site sample value of $32.76 \pm 0.51 \mathrm{mgHCN} / \mathrm{kg}$. Cyanide level of D. dumetorum (wild) $43.88 \pm 2.39 \mathrm{mgHCN} / \mathrm{kg}$ was also significantly $(\mathrm{p}<0.05)$ higher than $41.06 \pm 0.94 \mathrm{mgHCN} / \mathrm{kg}$ at the control site. At the effluent contaminated site $D$. rotundata cyanide content was $10.13 \pm 1.90 \mathrm{mgHCN} / \mathrm{kg}$ which was not significant at $(\mathrm{p}<0.05)$ compared to $9.65 \pm 1.36 \mathrm{mgHCN} / \mathrm{kg}$ for samples from the control site. There is also significant difference $(\mathrm{p}<0.05)$ in cyanide levels of $D$. alata samples from control and effluent contaminated sites $9.12 \pm 0.93$ and $8.45 \pm 1.60 \mathrm{mgHCN} / \mathrm{kg}$ respectively. X.sagittifolium and $C$. esculenta have significantly $(\mathrm{p}<0.05)$ higher cyanide concentrations at the cassava effluent site compared to the control 15.19 \pm 1.61 and $11.81 \pm 1.19 \mathrm{mgHCN} / \mathrm{kg}$ compared to $14.77 \pm 1.13$ and $10.89 \pm 1.55 \mathrm{mgHCN} / \mathrm{kg}$ respectively. There are no significant differences at $\mathrm{p}<0.05$ for I.batatas (red) cyanide levels for both sites: $6.75 \pm 1.19$ and $6.13 \pm 0.70 \mathrm{mgHCN} / \mathrm{kg}$, respectively, while $I$. batatas (white) cyanide level $8.44 \pm 1.20 \mathrm{mgHCN} / \mathrm{kg}$ for waste water contaminated site is significantly $(p<0.05)$ higher than $7.26 \pm 1.34 \mathrm{mgHCN} / \mathrm{kg}$ for samples from the control site.

\section{DISCUSSION}

The higher cyanide levels of the root tuber samples from the waste water contaminated site shows that the cyanide levels of the tubers may have been influenced by the effluent (waste water) from the cassava processing plant. Cyanide occurs naturally in a variety of fruits, vegetables and grains, while some plants also absorb cyanide from the soil [8]. Padmaja [24] and Onabolu et al. [1] reported that cyanide can be found in most plants in the form of cyanogenic glycoside. Ingestion of cyanide containing staple foods such as cassava and forage plants have accounted for many instances of cyanide poisoning in humans and animals. The exposure of persons to gaseous cyanide leading to intoxication by inhalation causes acute cyanide poisoning, while dietary exposure may occur as a result of high intake of the products of some nutritive plants of different root tubers; which contain cyanogenic glycosides [4,2]. On hydrolysis, these cyanogenic glycosides liberate hydrogen cyanide. Eating some foods like almonds, apricots, peach pits, root tubers are various means through which man gets exposed to cyanide.

Jorgensen [8] reported that plants that are grown in soil with low potassium content or high nitrogen have high hydrocyanic acid concentration in their tubers; and also as the plants get older, the hydrocyanic acid content of the tubers increases, attains a peak and then begins to decline. The ingestion of cyanide or a cyanogenic glycoside can

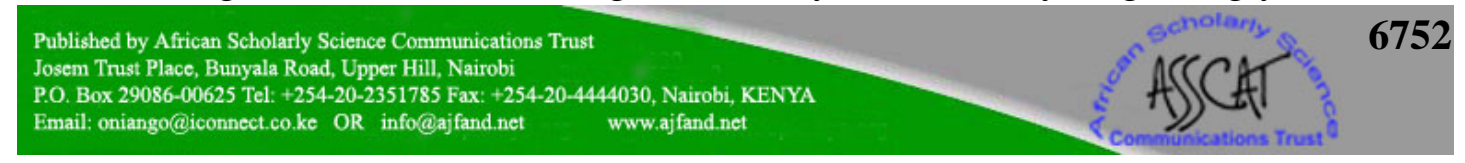


trigger off a lot of toxic manifestations. Ingestion of acute and innocuous levels of cyanide is known to cause instant death and a number of debilitating neurological disorders, respectively [3, 4]. Following ingestion of cyanogenic glycosides; cyanide ions are rapidly absorbed from the gastro-intestinal tract (GIT). Several cases of cyanide poisoning have been reported in humans and animals. Cyanide intake from cassava dominated diet has been proposed as a contributing factor in two forms of nutritional neuropathies; Tropical Ataxic Neuropathy (TAN) described from Nigeria and Epidemic Spastic Paraparesis (ESP) described from Mozambique [25]. The clinical picture of these diseases was dominated by damage to one of the sensory tracts in the spinal cord resulting in an uncoordinated gait called ataxia [2]. A strong association between Epidemic Spastic Paraparasis (ESP) and high dietary intake of cyanide and low intake of sulphur needed for cyanide detoxification has been confirmed [3]. Cassava diets poor in iodine have also been implicated in high incidence of endemic goiter in areas of high consumption [24].

Also cyanide exposure which interferes with iodine metabolism is a possible cause of spinal cord damage [4]. Repeated oral ingestion of sub-lethal doses of cyanide can also lead to chronic neurological problems, as two neurological syndromes resulting from chronic exposure to cyanide have been identified in humans. These are Lebers' disease and tobacco amblyopia which are caused by hydrocyanic acid contained in tobacco smoke [26]. In animals, the symptoms of hydrocyanic acid poisoning are increases in rate and depth of respiration, increased pulse rate, no response to stimuli and spasmodic muscular movements. It is also reported that the most common characteristics of cyanide poisoning in animals are dark muscle tissue, congestion or hemorrhage of the lungs, patechination of the tracheal mucosa and a frothy bloody damage from the mouth and nostrils [27]. In man, the sequence of events in acute poisoning are hyperventilation, headache, collapse and coma, nausea and vomiting, generalized weakness, perhaps with convulsion and then respiratory depression. With large doses, collapse, coma and death may occur [4]. Cyanide, carbon monoxide, hydrogen sulphide and azide effectively inhibit cytochrome oxidase. They prevent the mitochondrial oxidation as well as phosphorylation. ATP synthesis (phosphorylation) is dependent on electron transport. Hence inhibitors of electron transport chain also inhibit ATP formation. These compounds inhibit electron transport in cells in which such transport is coupled with ATP-synthesis, but they do not affect electron transport in cells in which transport is not coupled with phosphorylation[28]

Observations also show that plants can also take up cyanide from soils polluted by organic salts containing cyanide ion $\left[\mathrm{CN}^{-}\right]$or cyanides from industrial wastes as reported by El-Sharkang [29]. The cyanide levels of these root tubers may not pose any considerable danger to consumers since their average cyanide content is still below the estimated maximum sub-lethal dose of $20 \mathrm{mgHCN} / \mathrm{kg}$ [1]. Also the processing methods: cooking, frying, boiling may further decrease these cyanide levels. 


\section{CONCLUSION}

Other factors that may influence the cyanide levels of these root tubers include the soil type, since different soil types would retain cyanide to a varying degree. The age of the processing plant and by extension the age of the cassava waste water effluent and the specie of the cassava that is most processed would also influence the cyanide content of these root tubers.

This study, therefore, has provided results that show some root tubers grown on a cassava effluent waste water) contaminated soil could have their cyanide contents increased.

This speculation thus raises concern for people who may end up amassing toxic levels of cyanide from chronic low-level intake from these root tubers. Further investigations into the level of exposure of consumers and the systemic bioavailability of the cyanide upon consumption of the tubers and the short and long term toxicological implications and impact on consumers' health are recommended among the population.

In conclusion, though cyanide is sparingly soluble in water and can be drastically reduced during cooking of these tubers, the fact still remains that if the tubers are not properly processed, consumers may be exposed to lethal dose levels of cyanide which may be unsafe and could cause acute poisoning if not instant death. It is therefore recommended, proper disposal methods for garri processing effluents and discourage the planting of tubers and crops on lands contaminated by the effluents. 
Table 1: Cyanide levels of root tubers (mgHCN/kg)

\begin{tabular}{llll} 
Sample & Common Names & Control site & Waste water site \\
Dioscorea dumetorum & Domestic yam & $32.76 \pm 0.05^{*}$ & $35.49 \pm 1.69^{*}$ \\
Dioscorea dumetorum & Wild yam & $41.06 \pm 0.94^{*}$ & $43.88 \pm 2.39^{*}$ \\
Dioscorea rotundata & White yam & $9.65 \pm 1.36$ & $10.13 \pm 1.90$ \\
Dioscorea alata & Water yam & $8.45 \pm 1.60^{*}$ & $9.12 \pm 0.93^{*}$ \\
Xanthosoma sagittifolium (red) & Cocoyam & $14.77 \pm 1.33^{*}$ & $15.19 \pm 1.61^{*}$ \\
Colocasis esculenta (white) & Cocoyam & $10.89 \pm 1.55^{*}$ & $11.81 \pm 1.19^{*}$ \\
Ipomea batatas (red) & Sweet potato & $6.13 \pm 0.70$ & $6.75 \pm 1.19$ \\
Ipomea batatas (white) & Sweet potato & $7.26 \pm 1.34^{*}$ & $8.44 \pm 1.20^{*}$ \\
\hline
\end{tabular}

Values are mean \pm SD of triplicate determinations. Values with asterix vary significantly 


\section{REFERENCES}

1. Onabolu AO, Oluwole SO, Bokanga M and H Rosling Ecological variation of intake of cassava food and dietary cyanide load in Nigerian communities. Public Health Nutri. 2001; 4(4):871-876.

2. Oluwole OS, Onabulu AO, Cotgreave IA, Rosling H, Persson A and $\mathbf{H}$ Link Incidence of endemic ataxia polyneuropathy and its relation to exposure to cyanide in a Nigerian community. J. Neurol. Neurosurg. Psychiatry 2003;74 (10):1417- 1422.

3. Pitchumoni CS, Jain NK, Lowenfels AB and EP DiMaqno Chronic cyanide poisoning: unifying concept for alcoholic and tropical pancreatitis. Pancreas 1988;3(2):220-222.

4. Kamalu BP The adverse effect of long term cassava (Manihot esculenta Grantz) Consumption. Int. J. Food Sc. Nutri. 1995; 46(1):65-93.

5. Kemdirim OC, Chukwu AO and SC Achinewhu Effect of traditional processing of cassava on the cyanide content of garri and cassava flour. Plant Foods Hum. Nutri.1995; 48(4):335-339.

6. Okolie NP and RQ Omoigborule Differential effects of cooking in open cups and in sealed cellophane bags on the residual cyanide content of moimoi, a processed legume product. Food Chem. Toxicol.1999; 37(7):741-743.

7. Siriunga $\mathbf{D}$ and $\mathbf{R}$ Sayre Transgenic approaches for cyanogen reduction in cassava. J.AOAC Int. 2007; 90(5):1450-1455.

8. Jorgensen K, Bak S, Busk PK, Sorensen C, Olsen CE and BL PuontiKaerlas Cassava plant with depleted cyanogenic glucoside content in leaves and tubers. Distribution of cyanogenic glucosides, their sites of synthesis and transport, and blockage of the biosynthesis by RNA interference technology. Plant Physiol.2005; 139(1):363-374.

9. Phambu N, Meya AS, Djantou EB, Phambu EN, Kita-Phambu P and LM Anovitz Detection of residual cyanide in cassava using spectroscopic techniques. J. Agri. Food Chem. 2007; 55(25):10135-10140.

10. Onyesom I and PN Okoh Qualitative analysis of nitrate and nitrite contents in vegetables commonly consumed in Delta State -Nigeria. Br. J. Nutri. 2006; 96(5):902-905.

11. Siller $\mathbf{H}$ and $\mathbf{J}$ Winter Treatment of cyanide-containing wastewater from the Food industry in a laboratory-scale fixed-bed methanogenic reactor. Appl. Microbiol. Biotechnol. 1998; 49(2):215-20. 
12. Oluwole OS and AO Onabulu High mortality of subjects with endemic Polyneuropathy in Nigeria. Acta Neuro. Science. 2004; 150(20):94-99.

13. Lehininger AL Principles of Biochemistry. $13^{\text {th }}$ ed. Worth Publishers Inc. New York 2005. pp 483.

14. Oluwole OS, Onabulu AO, Cotgreave IA, Rosling H, Persson A and $\mathbf{H}$ Link Low prevalence of ataxia polyneuropathy in a community with high exposure to cyanide from Cassava foods. J. Neurol. 2002; 249(8):1934-1040

15. Oboh $\mathbf{G}$ and $\mathbf{M}$ Ekporigin Nutritional evaluation of some Nigerian wild seeds. Nahrung 2004; 48(2):85-87.

16. Eka OU The chemical composition of yam tubers. In: Advances in yam research, the Biochemistry and technology of yam tubers. Vol. 1 Osuji G (Ed). Biochemical Society of Nigeria. ASUTECH. Enugu. Nigeria. 1998. pp 51-57.

17. FAO/WHO. Food Standard Programmes. Cordex Alimentarius Commission XII supplement 4. 1991. FAO Rome Italy.

18. Philips T Cassava potential in producing countries. In: Global cassava market study: Business opportunities for the use of cassava” assembled by dTp studies, Inc. Guelph, Ontario. Canada, Mimeo. 1998.

19. Scott GJ, Best R, Rosegrant MW and M Bokanga Roots and tubers in the Global food system. A vision statement to the year 2020. Report of the Committee on Inter- Center Root and Tuber Crops Research (CICRTCR) in the CGIAR. A co-publication of CIAT, IITA, IPGRI, and CIP. Lima, Peru. 2000.

20. World Bank (IBRD). World Bank bulletin. African Development Indicators 2000, Washington DC, World Bank. 2000.

21. Nweke FJ, Okorji EC, Njoku JE and DJ King Expenditure elasticity's of demand for major food items in South East Nigeria. Tropical Agriculture. (Trinidad). 1994; 17(3):229-234.

22. Aregheore EM and OO Agunbiade The toxic effect of cassava (Manihot esculenta Grantz) diets in humans. Vet. Hum.Toxicol. 1991; 33(3):274-275.

23. AOAC. Official methods of analysis of the Association of Analytical Chemists. Horowotz, W and GW Latin [Eds] 18 ${ }^{\text {th }}$ ed.2005. p 14.

24. Padmaja G Cyanide detoxification in cassava for food and feed users. Crit. Rev. Food Sci. Nutri. 1995; 35(4):299-339. 
25. Famuyiwa OO, Akanji AO and BO Osuntoku Carbohydrate tolerance in patients with tropical ataxic neuropathy - a human model for chronic cyanide intoxication. Afr. Med .Med. Sc.1995; 24(2):151-157.

26. Oluwole SO, Onabulu AO, Link $\mathbf{H}$ and $\mathbf{H}$ Rosling Persistence of tropical ataxia Neuropathy in a Nigerian community. J. Neurol. Neurosurg. Psychiatry. 2000;69(1): 96-101.

27. Fitzgerald TD, Jeffers PM and D Mantella Depletion of host- derived cyanide in the gut of the eastern tent caterpillar, Malacosoma americanum. J.Chem. Ecol. 2002; 28(2):257-268.

28. Satyanarayana $\mathbf{U}$ and $\mathbf{U}$ Chakrapani Biological Oxidation In: Essentials of Biochemistry (2nd edition) 2009. 118-126. Arunbha Sen. Books and Allied (P) Ltd Kolkata 700009.

29. El-Sharkang MA Cassava biology and physiology. Plant Mol. Biol. 2004;56(4):481-501. 